\section{Marijan Stevanovski ${ }^{1}$}

MIT University Skopje, Faculty of Management

Dori Pavloska - Gjorgjieska ${ }^{2}$

MIT University Skopje, Faculty of Management
SCIENTIFIC REVIEW ARTICLE

doi:10.5937/ekonomika1601113S

Received: October 13, 2015

Accepted: December 14, 20

\title{
ELECTRONIC COMMERCE AS AN INTEGRAL PART OF THE DIGITAL ECONOMY WITH EMPHASIS ON ITS APPLICATION IN THE REPUBLIC OF MACEDONIA
}

\begin{abstract}
The modern world is faced with the application of means provided by modern information and digital technology. They impact processes through which elements of the business change, as well as the forms of management. This results in an eminent process of fast creation of appropriate solutions. The electronic system of operation has a significant potential in achieving the goals of a business - retaining existing and winning new market positions. Electronic commerce is buying and selling products and services electronically. It covers a wide area because in itself it includes all forms of trade and services that create and circulate material values. This paper is devoted to the electronic commerce as an integral part of the digital economy. It contributes to the growth of not only the company's sphere but also the wider society. Digitalisation enables expansion of activity, creating new directions in the development of the company.
\end{abstract}

Key words: digital economy, trade, social, company, technology

JEL classification: $\mathrm{O} 33$

\section{ЕЛЕКТРОНСКА ТРГОВИНА КАО САСТАВНИ ДЕО ДИГИТАЛНЕ ЕКОНОМИЈЕ СА НАГЛАСКОМ НА ЊЕНУ ПРИМЕНУ У РЕПУБЛИЦИ МАКЕДОНИЈИ}

\begin{abstract}
Апстракт
Савремени свет се суочава са применом средстава која су предвиђена за савремене информационе и дигиталне технологије. Ова средства утичу на елементе процеса пословне промене, као и облике управљања. То доводи до еминентних стварања одговарајућих решења у прочесу брзог пословања. Електронски систем рада има значајан потенцијал у остваривању цииьева бизнис - задржавање постојећих и освајање нових тржишних позиција. Електронском трговином се купују и продају производи и услуге електронским путем. Она покрива широко подручје, јер у себи обухвата све облике трговине и услуга које стварају материјалну вредност. Овај рад је посвећен електрон-

\footnotetext{
${ }^{1}$ marijan.stevanovski@mit.edu.mk.

22dori.pavloska@mit.edu.mk.
} 
ској трговини која је саставни део дигиталне економије, која доприноси расту не само у области компаније, већ и иирем друштву. Дигитализација омогућава проширење активности, стварање нових праваца у развоју компаније.

Кључне речи: дигитална економија, трговина, друштвена, компанија, технологија.

\section{Introduction}

Electronic commerce is defined as the buying or selling of goods and services through electronic media and electronically. The development of digital technology is causing profound changes in society (Kuznetsova, Vorobeva, 2015). Prospects of digital technology are large and they cause positive changes that reflect on all segments of the human life (Wright, Dyer, 2000). Very often e-commerce is defined as a process of management of online transactions by individuals or companies. This process includes both, retail and wholesale. Electronic commerce essentially refers to the system and procedures through which exchange of various financial documents and information happen.

Often the digital process operation is identified with the term virtual value chain (Stevanovski, 2012). The value chain includes the processes that companies have to perform in order for products and services to be available on the market. Thereby, the system can be conventional or digital.

The conventional system consists of components that are shown in Figure 1.

Figure 1. Conventional system of values on sales

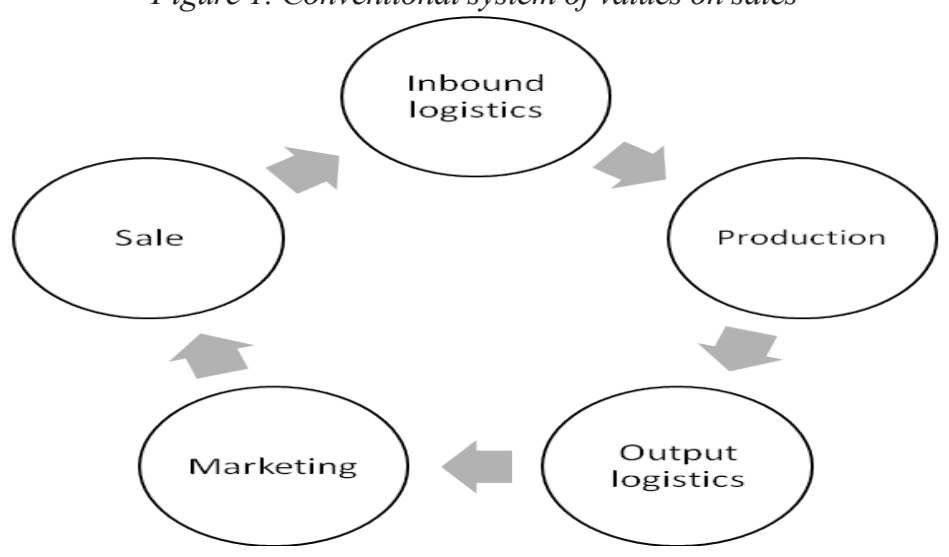

Source: T. Vassos, Strategical marketing on Internet, CET Computer Equipment and Trade, 2001

The virtual value chain is different and incorporates other values actually simplifying the whole process of trade, shown in figure 2. 
Figure 2. Algorithm of e-commerce

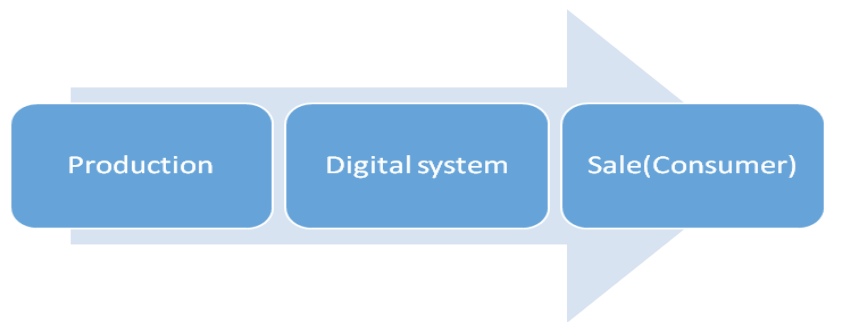

Source: T. Vassos, Strategical marketing on Internet, CET Computer Equipment and Trade, 2001

Electronic commerce in itself includes several activities such as distribution, purchasing, sales, marketing, servicing of products and services by using electronic systems. In itself, it includes a complete subsystem for use: electronic money, electronic marketing, electronic exchange of information and automated systems for data collection. This process allows the creation of a virtual value chain. Thus, "all business ventures today compete in a complex environment, comprised of: real world of tangible resources and virtual world of information" (Stevanovski, 2012).

Electronic commerce consists of two segments: (Tapscott, 1998):

- Telecommunication - sharing business information, maintaining business relationships and conducting business transactions which take place by means of a telecommunication network

- Network processes - the exchange of products, goods, services and information are going through computer networks.

In observation of the electronic commerce logical question is the electronic market. The electronic market is different from the traditional. Despite upholding primarily on its core function - meeting of buyers and sellers (in electronic commerce this process is virtual) - the electronic market reduces the entry barriers for access to the necessary information related to products and demand (Gray, 2015).

Besides the basic components of trade, the electronic commerce in itself includes all the processes that are directly related to the sales and post sales that are incorporated in the value chain (Wagner, Sweeney, 2010). The essence of e-commerce is actually a digital work which in itself incorporates the basic components such as: product, process and participants. The three elements themselves have two main dimensions: physical and digital (Tapscott, 1998).

Electronic information is the basic component of the electronic commerce. Electronic data interchange (EDI-Electronic Data Interchange) is a standardized and integrated system for the exchange of business documents using computer systems and networks.

In order to operate the system without any problems, it is regulated by appropriate standards. EDIFACT is an international standard applied since 1986. It is coupled with an interagency agreement on cooperation in the area of EDI, ISO and IEC. This agreement provides for mutual collaboration among all segments, including the International Telecommunication Union (ITU). 


\section{Materials and Methods}

The methodological approach in this paper covers the latest achievements of the modern digital economy, e-commerce, Internet and e-banking. The paper uses different methods of scientific research, such as methods of analysis, methods of comparison, a historical overview of the situation as well as data and views used by the experiences of employees in various institutions primarily in the commercial sector.

\section{Conditions for development of electronic commerce}

While it is difficult to formulate all the conditions required for the development of electronic commerce, we can distinguish four basic prerequisites, as shown in Figure 3 (Stevanovski, 2012).

Figure 3. Prerequisites for the development of electronic commerce

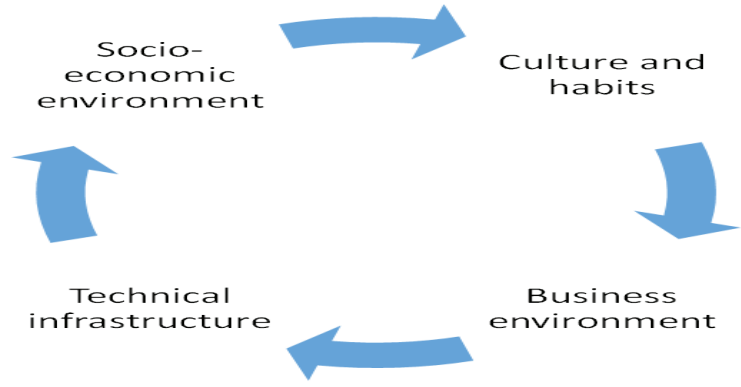

Source: M. Stevanovski, Management information system, Virtual-M, 2012

Socio-economic environment needs to be stable especially in terms of inflation and prices. If this condition is not met, then the electronic commerce is faced with direct problems. It may be difficult to carry out operations through the electronic system if a rise in prices in the period of execution of cash transactions happens. This requires a proper, thorough legal regulation in the area of operation of the electronic trading system (Zhang, Khan, Shih, 2015).

Culture and habits are gradually changing (Vida et al, 2015). Buyers develop habits to buy products and services from the comfort of their homes and that contributes to the development of the electronic commerce.

Business environment should enable a continuous process of construction and development (Alrough, Al-Debei, Ghinea, 2010). These include not only the electronic system of trade, but also systems that are directly involved in the finalization of the exchange, such as the banking system through the system of payment cards, which indirectly stimulates the process of electronic commerce.

Technical infrastructure is important because stable technical conditions are the basis of a functional system of electronic commerce. Given the great importance of the Internet, ISPs are key factors for the development of electronic trade. Stable internet service is necessary for the proper existence of electronic commerce (Yoo, 2010). 
The concept of electronic commerce can take several forms, including (Stevanovski, 2009):

- Web stores

- Internet banking,

- Internet exchanges

- Internet auctions

- nternet intelligence.

Web stores provide Internet access 24 hours a day without any limitations. The web store includes the following elements:

- Online store

- $\quad$ Payment processing

- Shipping / order fulfilment

- Customer service

- Promotion

Online store - For smooth functioning it is necessary to use appropriate software that assists in the implementation of electronic commerce. Making an online shop with HTML language will not meet the necessary requirements and will have direct implications on all promotional and sales systems.

Providing the recovery - system recovery may be direct or indirect. In a direct system, the seller creates a Merchant Account in a bank that has a system for electronic collection. The seller concludes a direct contract with the bank, which provides all the technical requirements for the implementation starting from an SSL server to a device that checks the validity of the cards. The system is considered to be serious and it is used by companies who prefer an electronic operating system. The indirect collection system is implemented through appropriate web services. The system is suitable for sale for which there is no adequate continuity.

Providing delivery - products and services, if allowed by their technical features, can be delivered and completed electronically. Otherwise, they use various forms of fast delivery to the buyer.

Customer service - Customer service needs to be available and functional to the buyers.

Promotion - quality and applicability of the product are the best promotional asset. Therefore the word of mouth from the customers and the advantages of the product are key market advantages. The buyer appreciates any kind of extra value to the product offered.

Online banking - Main features of electronic banking are: (Selty, 2003):

- Individuality;

- Mobility;

- Time and spatial independence;

- Flexibility and interaction.

Electronic banking offers tremendous advantages such as (Dave, 2002):

- Reduces the number of employees and permanently improves the quality of banking services;

- $\quad$ Reduces the number of organizational units and covers more territory;

- Increases the number of users to whom services can be delivered;

- $\quad$ Reduces the fees; 
- $\quad$ Services are not time limited, but available 24 hours, 365 days a year;

- The processing of transactions and their control is carried out at a given moment;

- Interactivity of banking provides great innovation;

- Increases the competitiveness of the banks.

Customers of the banks are unlimited and do not depend on the extent of their operations, as well as the size of the business. The services most commonly used are:

- Transfer of funds;

- Reporting on the state of the accounts;

- Manage ready cash;

- Using domestic banking;

- Using telephone banking.

The internet is used in order to carry out activities of electronic banking. Security is a priority factor in the process of operation (Herrmann, Tavakolifard, 2010, p. 3). Therefore, a lot of funds, knowledge and skills are used to improve Internet security in banking institutions.

The Internet is emerging as a major medium through which the process is implemented (Mladenovic, Cuzovic, 2014) in a much faster and cheaper mode.

Internet banking is used in many areas such as:

- Support business processes in banking,

- Implementation of banking transactions with online communication,

- Electronic checks,

- Electronic money,

- $\quad$ Payment cards.

Although at the beginning the payment via internet had no extensive application, the software development enabled the application of new instruments in the process of conducting bank transactions, with this payment method becoming extremely promising for the future.

The first Internet markets are dated from 1996. Two small companies offered their securities online. But because there was no secondary market, transactions were considered too risky. Spring Street Brewing Company (SSBC) offered its securities with the tendency to create a secondary market for securities. This led to the creation of Wit Trade, an Internetbased bulletin board containing two components: one for sale and one for purchase.

The online transactions in securities do not exclude the services of brokers. The correct choice of broker is the basis for success. The online markets are opening an account through which the transactions occur. Investing begins with providing the necessary funds to the bank account or deposit with a broker. The Internet offers many benefits, but also risks. Investors easily put their money there and there are realistic conditions for abuse.

Internet auctions, through this kind of e-commerce, achieve the largest turnover of money and goods.

\section{Internet Security}

Internet as a public network is available to all. Thus, the opportunity for abuse is great and outstanding (Kim, Ferrin, Rao, 2008). Therefore, it is necessary to provide:

- Confidentiality of information 
- Prevention of unauthorized use

- Authentication of information.

Cryptography deals with methods and techniques used in order to solve this problem. Through encryption, decrypting and using keys, the system security increases. The information that is not encrypted and travels over the internet is a subject of opportunities for misuse. Therefore, methods that increase the level of security are developed (Powell, Conca, 2015).

Security can be categorized as:

- Using offline mode of communicating all security elements that can degrade the message

- Using backup servers through protocols used to transmit data between the web server and reader.

- Development of secure online system transactions: First Virtual, Caber Cash.

\section{Development of Electronic Commerce in Republic Of Macedonia}

There are favourable conditions for electronic commerce in the Republic of Macedonia, which is contributing to its steady growth. In 2010 there were only 10 electronic stores, but their number drastically increased to more than 250 electronic stores at the end of 2013. In $201450 \%$ of the businesses had their own web pages and $10 \%$ processed online orders (www.stat.gov.mk).

The growth of electronic commerce is primarily due to the growing need of customers to shop 24 hours a day, the need for convenience, and the existing legal regulations in the area of electronic operations.

Research shows that customers in the Republic of Macedonia expressed a desire to shop online, but if the necessary level of safety and variety of products is ensured. Most Internet users expressed a desire to purchase: electronic and computer equipment, clothing, shoes and gifts. The least bought products via the Internet are food products and beverages. Macedonian customers prefer lower prices and free home delivery of products purchased.

There are processing centers in Macedonia, such as: Currant, First data and the processing center of Halk Bank. The tables below present information related to the electronic operations, including electronic commerce in the country. 
Table 1. Information and communication technologies in the enterprises according to the number of employees, 2014

\begin{tabular}{|c|c|c|c|c|}
\hline \multirow[t]{3}{*}{ in $\%$} & \multirow{3}{*}{$\begin{array}{l}\text { Total } \\
(10+) \\
\end{array}$} & & & \\
\hline & & \multicolumn{3}{|c|}{$\begin{array}{l}\text { Enterprises according to the number of } \\
\text { employees }\end{array}$} \\
\hline & & $(10-49)$ & $(50-249)$ & $(250+)$ \\
\hline 1 & 2 & 3 & 4 & 5 \\
\hline Enterprises, total & 100,0 & 100,0 & 100,0 & 100,0 \\
\hline Enterprises with computers & 94,6 & 93,9 & 98,3 & 99,0 \\
\hline Enterprises with Internet access & 93,1 & 92,1 & 98,3 & 99,0 \\
\hline $\begin{array}{l}\text { - via fixed broadband connection (DSL, cable, fiber optics or other } \\
\text { technology) }\end{array}$ & 92,1 & 90,9 & 98,1 & 99,0 \\
\hline - via mobile telephone network (broadband or other mobile connection) & 59,3 & 57,1 & 68,2 & 80,2 \\
\hline Broadband connection (fixed or mobile) & 93,1 & 92,0 & 98,3 & 99,0 \\
\hline $\begin{array}{l}\text { Provided to the persons employed portable devices that allow a mobile } \\
\text { connection to the Internet for business use }\end{array}$ & 60,7 & 58,5 & 69,3 & 81,8 \\
\hline Have a web site or a homepage & 53,2 & 49,8 & 66,2 & 88,5 \\
\hline - enterprise's website providing online ordering, reservation & 12,4 & 12,2 & 13,7 & 11,8 \\
\hline Used social media (but not only for paid advertise) & 36,8 & 37,0 & 34,5 & 44,6 \\
\hline Have bought a Cloud computing service used over the Internet & 11,9 & 11,8 & 11,7 & 15,4 \\
\hline Have ERP software package to share information & 21,6 & 18,6 & 30,9 & 61,1 \\
\hline Have CRM software for managing information about its clients & 20,0 & 18,3 & 25,3 & 43,2 \\
\hline Have CRM to analyse information about clients for marketing purposes & 16,4 & 14,9 & 21,8 & 34,9 \\
\hline $\begin{array}{l}\text { Electronic Data Interchange in a format that allowed its automatic } \\
\text { processing (EDI-type messages) }\end{array}$ & 40,9 & 37,9 & 53,5 & 66,7 \\
\hline - EDI-type messages for payment instructions to financial institutions & 29,4 & 27,3 & 39,6 & 40,4 \\
\hline - send / receive EDI-type messages for data to/from public authorities & 37,4 & 34,4 & 50,6 & 58,6 \\
\hline $\begin{array}{l}\text { Share supply chain management information electronically with suppliers } \\
\text { or customers }\end{array}$ & 13,6 & 13,0 & 14,6 & 26,2 \\
\hline - via websites or web portals & 10,3 & 10,2 & 10,0 & 13,1 \\
\hline $\begin{array}{l}\text { - via electronic transmission suitable for automated processing (e.g. EDI- } \\
\text { type systems, XML, EDIFACT, etc.) }\end{array}$ & 5,7 & 5,0 & 7,5 & 18,6 \\
\hline Sent e-Invoices, 2013 & 26,3 & 25,3 & 30,9 & 31,4 \\
\hline $\begin{array}{l}\text { - sent e-Invoices in a standard structure suitable for automatic processing } \\
\text { (e.g. EDI, UBL, XML) }\end{array}$ & 6,2 & 5,8 & 8,5 & 7,7 \\
\hline - sent e-Invoices, not suitable for automatic processing (e.g. PDF) & 25,7 & 24,9 & 29,6 & 28,8 \\
\hline $\begin{array}{l}\text { Received e-Invoices in a standard structure suitable for automatic } \\
\text { processing, } 2013\end{array}$ & 12,6 & 12,0 & 15,8 & 11,3 \\
\hline $\begin{array}{l}\text { Sent or received e-Invoices in a standard structure suitable for automated } \\
\text { processing, } 2013\end{array}$ & 13,9 & 13,4 & 16,8 & 14,7 \\
\hline RFID for person identification or access control & 12,7 & 9,5 & 24,5 & 47,0 \\
\hline $\begin{array}{l}\text { RFID for monitoring and control of industrial production and service } \\
\text { delivery process }\end{array}$ & 5,5 & 4,5 & 9,1 & 17,9 \\
\hline $\begin{array}{l}\text { RFID for product identification after the production process (theft control, } \\
\text { counterfeiting, etc.) }\end{array}$ & 4,6 & 3,9 & 6,7 & 13,3 \\
\hline Enterprise employed ICT specialists & 13,7 & 9,9 & 26,3 & 63,3 \\
\hline Have provided training to develop ICT skills of personnel, 2013 & 13,7 & 11,2 & 21,5 & 48,2 \\
\hline - for ICT specialists & 5,4 & 4,1 & 8,2 & 31,0 \\
\hline
\end{tabular}




\begin{tabular}{|l|r|r|r|r|}
\hline - for other persons employed & 12,1 & 9,8 & 19,8 & 41,8 \\
\hline Have recruited or tried to recruit ICT specialists, 2013 & 5,1 & 4,1 & 8,1 & 20,1 \\
\hline Had hard-to-fill vacancies for ICT specialists, 2013 & 1,9 & 1,7 & 3,1 & 2,3 \\
\hline
\end{tabular}

Source: www.stat.gov.mk

Table 2. E-commerce in the enterprises, according to the number of employees, 2013

\begin{tabular}{|c|c|c|c|c|}
\hline \multirow[t]{2}{*}{ in $\%$} & \multirow{2}{*}{$\begin{array}{l}\text { Total } \\
(10+)\end{array}$} & \multicolumn{3}{|c|}{$\begin{array}{l}\text { Enterprises according to the } \\
\text { number of employees }\end{array}$} \\
\hline & & $(10-49)$ & $(50-249)$ & $(250+)$ \\
\hline Enterprises that have e-commerce (e-sales or e-purchases) & 9,7 & 9,2 & 10,1 & 21,6 \\
\hline E-sales: have received orders via computer networks (web or EDI) & 7,0 & 6,8 & 7,3 & 10,7 \\
\hline $\begin{array}{l}\text { Web sales: received orders for products or services that were } \\
\text { placed via a website }\end{array}$ & 6,4 & 6,4 & 6,2 & 7,5 \\
\hline \multicolumn{5}{|l|}{$\begin{array}{l}\text { Percentage of the total turnover resulting from orders received via } \\
\text { website }\end{array}$} \\
\hline$=/>1 \%$ & 4,9 & 5,2 & 3,7 & 3,4 \\
\hline$<1 \%$ & 1,0 & 0,8 & 1,8 & 1,8 \\
\hline unknown & 0,5 & 0,4 & 0,7 & 2,3 \\
\hline \multicolumn{5}{|l|}{ Sales placed via a website by type of customer } \\
\hline B2C (Sales to private consumers) & 4,8 & 5,0 & 3,8 & 5,2 \\
\hline $\begin{array}{l}\text { B2B (Sales to other enterprises) and B2G (Sales to public } \\
\text { authorities) }\end{array}$ & 3,2 & 3,4 & 2,7 & 0,0 \\
\hline \multicolumn{5}{|l|}{ Means of payment for sales via a website } \\
\hline Online payment, i.e. payment integrated in the ordering transaction & 2,9 & 3,0 & 2,1 & 3,9 \\
\hline $\begin{array}{l}\text { Offline payment, i.e. payment process is not included in the } \\
\text { ordering transaction }\end{array}$ & 5,7 & 5,9 & 4,8 & 6,0 \\
\hline $\begin{array}{l}\text { EDI-type sales: received orders via EDI-type messages in an } \\
\text { agreed format, e.g. EDIFACT, UBL, XML }\end{array}$ & 1,1 & 0,9 & 1,5 & 3,9 \\
\hline \multicolumn{5}{|l|}{ Percentage of the total turnover resulting from EDI-type sales } \\
\hline$=/>1 \%$ & 0,7 & 0,6 & 1,1 & 0,8 \\
\hline$<1 \%$ & 0,2 & 0,2 & 0,2 & 1,6 \\
\hline unknown & 0,2 & 0,1 & 0,2 & 1,6 \\
\hline $\begin{array}{l}\text { ePurchases: placed orders for products/services via computer } \\
\text { networks - via a website or EDI-type systems }\end{array}$ & 5,0 & 4,7 & 4,7 & 15,0 \\
\hline Placed orders via website & 4,4 & 4,1 & 4,7 & 12,4 \\
\hline Placed orders via EDI-type messages & 2,2 & 2,2 & 0,9 & 7,7 \\
\hline \multicolumn{5}{|l|}{$\begin{array}{l}\text { Percentage of the total purchases that resulted from orders placed } \\
\text { electronically }\end{array}$} \\
\hline$=/>1 \%$ & 3,6 & 3,7 & 2,4 & 6,4 \\
\hline$<1 \%$ & 1,4 & 1,0 & 2,3 & 8,6 \\
\hline
\end{tabular}

Source: www.stat.gov.mk 


\section{Usage of information and communication technologies in enterprises, 2014}

According to the data of the State Statistical Office of the Republic of Macedonia (www.stat.gov.m), in January 2014, 93.1\% of the enterprises with 10 or more employees had a broadband connection to the Internet (via fixed or mobile broadband connection). Access to the Internet via a mobile connection (broadband or other mobile connection) was used by $59.3 \%$ of the enterprises. $60.7 \%$ of the enterprises provided to their employees portable devices that allow a mobile connection to the Internet for business use, but only $10 \%$ of the persons employed were using these devices (e.g. notebook, laptop, smartphone, PDA phone). Social Media (e.g. Facebook, LinkedIn, Twitter, Present.ly, YouTube, Flickr, Picassa, Wiki-tools, etc.) were used (but not only for paid advertising) by $36.8 \%$ of the enterprises. Cloud computing services used over the Internet were bought by $11.9 \%$ of the enterprises. $40.9 \%$ of enterprises were sending or receiving EDI-type messages in a format that allowed their automatic processing (e.g. EDI Electronic Data Interchange, UBL, XML), 21.6\% had ERP-software package to share information within the enterprise, and 20\% used CRM software for managing information about the clients. During 2013, 9.7\% of enterprises with 10 or more employees had e-commerce, i.e. buying or selling goods or services over computer networks (via websites or EDI-type systems), $6.4 \%$ of enterprises had web-sales, and $4.4 \%$ of enterprises made web-purchases.

\section{Conclusion}

The development of modern means of communication, especially electronics, is playing a significant role in the process of globalization. That leads to a thorough ongoing process of changing existing relations. Today electronic commerce and the general electronic way of working is used in areas where it was difficult or impossible to implement in the past.

The modern approach is characterized by the transformation from mechanical into electronic, leading to a rapid penetration of technical progress. The development of e-commerce leads to a series of advantages over the conventional method of functioning. However, in addition to the positive there are negative sides of this process, expressed through the security issues and the risk of abuse of the entire electronic system.

Electronic commerce has an impact on three factors:

- Economic,

- Technological and

- Social.

It is important to note that the progress of the electronic commerce continues and it is necessary to provide the required conditions for its smooth functioning having in mind that it benefits both sides of the market: buyers and sellers.

\section{References}

Alrouh, B.,Al-Debei, M. M., Ghinea, G. (2010)Developing a Decision-Making Framework for Web Service Security Profiles: A Design-Science Paradigm. Available at: http:// works.bepress.com/mutaz_al-debei/12 
Dave, C. (2002) E-Business and E-Commerce Management, Pearson Education Limited, Essex, UK.

Gray, J. (2015) Information Technology Valuation: A Strategy and Risk Based Approach. University of Redlands. Retrieved from http://inspire.redlands.edu/cas_honors/85

Herrmann, P., Tavakolifard, M. (2010) Special issue on trust and privacy in electronic commerce. Electronic Commerce Research, open access at Springerlink.com

Kim, D., Ferrin, D., Rao, H. R. (2008) A Trust-Based Consumer Decision Model in Electronic Commerce: The Role of Trust, Risk, and Their Antecedents, Decision Support Systems. Research Collection Lee Kong Chian School Of Business.

Kuznetsova, N. V., Vorobeva, N. A. (2015) Analysis of the aspects of changing the economic paradigms in the world economy, Ekonomika, 61(2), 55-68.

Mladenovic, S. S., Cuzovic, Dj. (2014) Development of the Concept of Corporate Social Responsibility in Trade under Conditions of Market Globalisation, Ekonomika. 60(4), $117-129$

Powell, C., M., Conca, C. (2015) Perceived Risk R1q3eduction In E-commerce Environments, Atlantic Marketing Association Proceeding, Savannah, Georgia.

Selty, J. (2003) Internet banking-an Overview, Journal of internet banking and commerce.

Stevanovski, M. (2009) Marketing information system, market research and pricing, MSI.

Stevanovski, M. (2012) Management information system, Virtual-M

Tapscott, D. (2015) The Digital Economy, McGraw-Hill Education

Tapscott, D., Lowy, A., Ticoll, D. (1998) Blueprint To The Digital Economy, McGraw-Hill

Vassos, T. (2001) Strategic Marketing on Internet, CET Computer Equipment and Trade

Vida, I. et al (2015). National Culture Dimensions and Consumer Digital Piracy: A European Perspective. Atlantic Marketing Association Proceeding, Savannah, Georgia

Wagner, C, Sweeney, E. (2010) E-Business in Supply Chain Management, IGI Global, Hershey PA 17033

Wright, P. M., Dyer, L. (2000) People in the E-Business: New Challenges, New Solutions. Cornell University, School of Industrial and Labor Relations, Center for Advanced Human Resource Studies. Ithaca, NY

Yoo, C. S. (2010) Innovations in the Internet's Architecture that Challenge the Status Quo, Legal Scholarship Repository, University of Pennsylvania Law School

Zang, J., Khan, M. R., Shih, D. (2015) Rating Determinants Factored in E-Commerce Decision Making. International Journal of Applied Management and Technology 2015, Volume 14, Issue 1, Pages 1-20. Walden University, LLC, Minneapolis, MN

http://www.stat.gov.mk/ 